\title{
Ajenifuja B Paediatrics Health Care in Nigeria: Yesterday, Today and Tomorrow
}

Received: 28th September 2011

Accepted: 28th September 2011

Ajenifuja B OFR $(\varangle)$

Faculty of Paediatrics National Postgraduate

Medical College Ijanikan Lagos. 2011 Guest

Lecturer,

Dr. Bolaji Ajenifuja served as Secretary of Faculty of Paediatrics of the National Postgraduate Medical College of Nigeria for the first 14years after its inception and organized the early postgraduate examinations in Paediatrics.

\section{My dear colleagues and guests,}

Thank you for allowing me to deliver this annual lecture of our Faculty. It is a great honour and privilege indeed, as I virtually requested to be staffed into this role.

Looking round I find that most of those brilliant men of paediatrics with whom we started this College over four decades ago have left the scene partly as a result of old age, some form of infirmity or even death. It appears that even as the best minds in medical jigsaw, we cannot not stop death in its onslaught. Therefore, as we progress to write the history of child health and life in Nigeria, it is imperative that we put the record straight for the coming generation to know how it all started and grew in Nigeria.

Paediatrics is that branch of medicine dealing with the medical care of infants, children and adolescents essentially up to the age of seventeen which is the age of majority in Nigeria. An American doctor Arthur Jacobi 18301919 has been acclaimed as the father of paediatrics because of his many contributions to this field of medicine. He was one of the early pioneers who drew attention to the link between the environmental milieu of children and their diseases.

Most of my colleagues assembled here today are paediatricians.
In Nigeria the path towards emergence of paediatric care by paediatricians has been very long and tortuous. In the pre-colonial era it was the traditional Health practitioners who passed knowledge from generation to the other. They earned their living through their art and so kept it as a guarded secret in the family. These local practitioners obviously treated children in addition to conducting birth of babies. Though they also used witchcraft and herbs, they were treated as experts in their own field.

Children especially females were subjected to female circumcision and newborn babies had their umbilical cord cut with bamboo stick. The result of this primitive treatment of children was high infant morbidity and mortality. As a result of the fetal wastage and childhood deaths, families tended to have more children to make up.

The advent of the Europeans by boat into the Nigerian sphere for trade subjected the foreigners to locally endemic diseases as malaria, yellow fever and diarrhea diseases. As could be expected quite a lot of the visiting traders succumbed to illnesses and those lucky to get back to their home destination transmitted the medical diseases to their destination. In response, the foreigners introduced some form of medical care for their staff and self.

The initial traders and later, the slave traders limited their activities to the shores while dealers in other commodities ventured into the hinterland. Other Europeans came as missionaries and made inroad into the hinterland by road and boat along the River Niger and its tributaries. This third wave of missionaries and trading explorers no doubt primed by stories of diseases, deaths of their predecessors brought some western medical care into Nigeria, the first of which was in the Benin districts.

Archives show that one Dr. Williams of Great Britain carried out several vaccinations sessions and dressing of ulcers in indigenous populations along the West Coast of Africa including Niger Delta up to Lokoja. 
Gradually, health care facilities were established followed by recruitment and training of human resources for health delivery. History also shows that European traders brought few doctors and nurse to look after themselves and their immediate host communities.

With time, the missionary societies, Catholic and Presbyterian, provided health facilities in Lagos, Abeokuta (Sacred Heart Hospital) and in south Eastern Nigeria. One notable example was Mary Slessor in Calabar. Reverend Hope Waddell from Ireland recruited colleagues who were not health professionals but were trained to give health treatment in clinics and dispensaries in and around Calabar. Archives also reveal that Reverend Waddell conducted the first vaccination against small pox in Calabar in the mid 1950s.

The Baptist mission and Qua Ibo mission established a number of dispensary and maternity services in southern Nigeria. The Ogbomosho Hospital and Iyi Enu Hospital near Onitsha in 1906 are living examples of their efforts. In the middle belt, the Sudan Interior Mission provided medical facilities as well.

The Baptist colonial government provided clinics and hospitals in Lagos and Calabar. The first government hospital was built in Calabar and was named Margaret Hospital in 1896. With time, health facilities spread to other parts of the country. Services were initially partly limited to Europeans, but later extended to African staff or European organizations.

During the First World War, bush hospitals constructed with grass thatch, bamboo and mud were built to meet military needs. Later European Hospitals called Nursing Homes and African Hospitals were built and these were made to become General hospitals.

In the early colonial era, the colonial masters made effort to establish specialized health institutions mostly in Lagos viz.

The Infection Diseases Hospital.

Mental Asylum in Lagos and Calabar.

Orthopaedic Hospital.

Massey Street Dispensary, 1903.

Father Coguard an ordained priest, with some medical training established the first leper settlements in 1897.

In 1877 Inspector of Nuisance was gazetted.

In 1897 a medical and sanitary department was created in Lagos.
Massey Street Dispensary was later upgraded to a maternity hospital in 1920. It metamorphosed into the FIRST CHILDREN HOSPITAL in West Africa in 1962. The Creek Hospital was built in 1925 by one Dr. G.M.Gray, but was later bought over by government.

\section{Development of human resources}

The colonial administration trained staff for health and other public service. The Religious mission also established institutions for training nurses and paramedical personnel. Examples of these are the Mission Hospitals in Shaki, Ogbomosho, Ilesa and Eku. In addition, the missions sponsored many of the first generation Nigerian doctors for professional training in Europe.

With the First World War 1914 to 1918, there was need for European Health personnel in war zones to cope with war victims. Army medical corps AMC was formed and this paved the way for government medical services in Nigeria in 1946.

As part of the 10 year development plan, the Federal Ministry of Health was established in 1946 to coordinate health services throughout the whole country. At that time Nigeria had a unitary form of government.

In 1948, the University College Ibadan (UI) was founded with a faculty of Medicine and a teaching hospital, University College Hospital (UCH). It started with fourteen students. I must point out that before the University of Ibadan was established, and precisely in 1930 the Yaba Medical School (YMS) was established to train a cadre of medical assistants.

The YMS was part of Yaba Higher College, a post secondary institution which folded up with the establishment of University of Ibadan. In 1954 Kano Medical School was inaugurated.

In 1937, records show that there were one hundred and thirty-five (135) doctors in Nigeria Medical Register one hundred and sixteen (116) Europeans and nineteen (19) Africans. Nearly a third of the Europeans were medical missionaries and a few were industrial medical advisers.

\section{Post-colonial era}

With independence in 1960 and attainment of Republic status in 1963, Nigeria became an automatic member of the WHO and the United Nations Organization (UNO). More than a decade later, the country still fell short of the WHO recommended one doctor to ten thousand patients. As of 1972 Nigeria had one doctor to twenty two thousand patients. 
Since 1960, Nigeria has adopted five successive National and twenty-four sectional health policies most of which were incorporated into the various national development plans. The last was adopted in 1988 during the Babangida regime when the Perspective Planning and National Health Policy were adopted.

\section{The Key Elements of the Policy}

Education on prevailing health problem and methods of preventing them.

The promotion of food supply and proper nutrition;

Material and child care including family planning;

Immunization against major infectious diseases.

Prevention and control of local endemic and epidemic diseases;

Provision of essential drugs and supplies

Primary Health care was seen as the goal of health for all people in the country.

Health remains in the concurrent list in the constitution of the Federal Republic of Nigeria, implying that Federal, State and Local authorities can exercise supervisory roles over health matters.

Though after independence each region was to develop at its own pace with little interference from the central government, incursion of military dictatorship indirectly overruled that by formulating legislation on health usually without consultation of the States. The National Council of Health considered draft National Policies as advisory forum twice a year. Militarism led to lack of true federalism thus depriving the States the initiative of implementation of their plans of health for the people though States like Lagos, Enugu and Anambra did initiate health facilities.

A lot of pressure exerted by other independent international agencies on developing countries like ours urged us to identify specific health problems and design to tackle them. This prodding helped the Nigerian authorities to formulate the National Health Policy in 1988. Once promulgated, a lot of effort was put into implementation between 1988 and 1992 under the stewardship of late Prof. Olikoye Ransome- Kuti apostle of primary health as minister of Health. There was $80 \%$ immunization coverage, a bold achievement. He later established the National Primary Health Care Development Agency in the country.
With the annulment of 1993 presidential election, most sectors of activities including health came to a near standstill and this continued for about five years. Despite Nigerians high human and material deposit, poverty was still rampant in Nigeria.

\section{The Structural Adjustment Programme (SAP)}

SAP led to exodus of medical personnel to the Middle East principally Saudi Arabia, the United Kingdom and the United State of America. The result of this was that in 2000, Nigeria ranked one hundred and eighty-seven (187) out of one hundred and ninety-one (191) member states of world Health Organization in decreasing order of health system performance.

\section{Funding of the National Health System}

Government provides major allocation
Payment by individuals for service and drug
purchases
Contribution by employees
Foreign loans and grants

Unbelievable, tertiary institutions receive two thirds of total budget allocation to health of which two third is spent on personnel and administrative exercises. Obviously, this type of disbursement leaves little for the main pursuits of excellence for which the institution is established. Worse still, delay in releasing required funds naturally leads to lack of maintenance of facilities. Repeated representations have been made to the Federal and State Governments to increase health service allocations in line WHO recommendations.

As an alternative or supplementary fund for the health system the National Health Insurance Scheme (NHIS) was started in 2005. The success or not of this scheme is still being evaluated as some believe there is inequity in its operation.

In a paper I presented in 1988 on the Nigerian Child in the International Perspective at the annual conference of Paediatric Association of Nigeria at Onitsha, Anambra State, I showed the following slides which I am showing today to stir our conscience on how far we have come since then in the welfare of the Nigeria child. 
Table 1: $\quad$ Situation of children in Asia and Africa

\begin{tabular}{lllll}
\hline Country & $\begin{array}{l}\text { Total population } \\
\text { (thousands) }\end{array}$ & $\begin{array}{l}\text { Population growth } \\
\text { rate (percentage) }\end{array}$ & $\begin{array}{l}\text { Children 0-14 total } \\
\text { population } \\
\text { (percentage) }\end{array}$ & $\begin{array}{l}\text { Infant } \\
\text { mortality rate } \\
\text { per } \mathbf{1 , 0 0 0}\end{array}$ \\
\hline Indonesia & $154^{\prime} 661$ & 1.9 & 39.3 & 90.3 \\
Bangladesh & $92^{\prime} 616$ & 2.3 & 14 & 122 \\
Pakistan & $87^{\prime} 130$ & 3.0 & 45.3 & 120 \\
India & $7044^{\prime} 240$ & 2.1 & 40 & 122 \\
Japan & $119^{\prime} 200$ & 0.7 & 23.9 & $7-1$ \\
\hline
\end{tabular}

Table 2: Tuberculosis and BCG

\begin{tabular}{llllll}
\hline Parameter & 1982 & 1983 & 1984 & 1985 & 1986 \\
\hline Population at risk (9\% Total) & 4,475 & $4,591,590$ & $4,710,290$ & $4,832,075$ & $4,957,065$ \\
BCC Vaccination Reported & 603,394 & 456,514 & 372,485 & 930,655 & $1,873,381$ \\
\% Population At Risk Vaccinated & 13.5 & 9.9 & 12.2 & 19.3 & 37.8 \\
Mid-Year Population Estimate & $89,518,600$ & $91,831,800$ & $94,205,800$ & $96,641,500$ & $99,141,300$ \\
Tuberculosis Cases Reported & 10,949 & 10,212 & 10,677 & 14,934 & 14,071 \\
TB Cases Per 100,000 POP & 12.2 & 11.1 & 11.3 & 15.5 & 14.2 \\
Tuberculosis Deaths Reported & 334 & 208 & 161 & 354 & 515 \\
TB Cases Fatality Rate (\%) & 3.05 & 2.04 & 1.51 & 2.37 & 3.66 \\
\hline
\end{tabular}

Table 3: Nigeria compared with a typical developed country

\begin{tabular}{lll}
\hline Details & Nigeria & A d eveloped country \\
\hline Crude live birth rate per 1,000 population & 48 & 16 \\
Crude death rate per 1,000 population & 16 & 9 \\
Rate of natural increase of population (\%) & 3.2 & 0.7 \\
Period needed to double the population (years) & 22 & 100 \\
Medium age (years) & 16 & 27 \\
Life expectancy at birth (years) & 54 & 74 \\
Proportion of deaths in < 6years old (\%) & 50 & 4 \\
Maternal mortality rate & 15 & 0.2 \\
Under 5year old mortality rate & 160 & 16 \\
Childhood (1-4year old) Mortality rate & 70 & 5 \\
Infant mortality rate & 90 & 11 \\
Percentage of popul ation under 15years (dependents) & 48 & 20 \\
15-64years (Labour Age Group) & 49 & 66 \\
65years and above (Senior Citizens) & 3 & 24 \\
\hline
\end{tabular}

Nigeria: Land area $=923,768 \mathrm{Sq}$ Kilometers

Key:Source $=$ National population Bureau, Lagos $($ January 1984) 
Table 4a: A history of the Nigerian health services: Lagos vital statistics 1900 - 1939

\begin{tabular}{cccc}
\hline Date & $\begin{array}{c}\text { Birth } \\
\text { rate }\end{array}$ & $\begin{array}{c}\text { Death } \\
\text { rate }\end{array}$ & $\begin{array}{c}\text { Infant mortality } \\
\text { rate }\end{array}$ \\
\hline 1900 & & & \\
1909 & $42.4 ?$ & 37.2 & 450 (per 1,000$)$ \\
1910 & $4.4 ?$ & 35.8 & 315 \\
1919 & 30.2 & 27.0 & 324 \\
1920 & 33.5 & 28.8 & 285 \\
1921 & 30.4 & 25.1 & 285 \\
1923 & 32.7 & 23.8 & \\
1924 & 32.2 & 26.9 & 236 \\
1927 & 28.9 & 20.2 & 175 \\
1930 & 28.6 & 16.5 & 129 \\
1931 & 24.9 & 12.6 & 112 \\
1932 & 27.5 & 12.9 & 102 \\
1933 & 24.9 & 13.8 & 137 \\
1934 & 27.8 & 13.0 & 119 \\
1935 & 26.3 & 13.9 & 129 \\
1936 & 23.8 & 13.8 & 140 \\
1937 & 22.9 & 23.3 & 130 \\
1938 & 24.0 & 21.6 & 127 \\
1939 & 27.6 & 21.4 & 127 \\
\hline
\end{tabular}

Table 4b: A history of the Nigerian health services: Lagos vital statistics 1940 - 1960

\begin{tabular}{cccc}
\hline Date & $\begin{array}{c}\text { Birth } \\
\text { rate }\end{array}$ & $\begin{array}{c}\text { Death } \\
\text { rate }\end{array}$ & $\begin{array}{c}\text { Infant mortality } \\
\text { rate }\end{array}$ \\
\hline 1940 & 29.3 & 22.5 & 132 \\
1941 & 28.3 & 21.6 & 114 \\
1942 & 31.5 & 25.4 & 124 \\
1943 & 24.8 & 23.2 & 140 \\
1944 & 37.3 & 29.1 & 116 \\
1945 & 45.0 & 23.3 & 128 \\
1946 & 46.0 & 19.0 & 110 \\
1947 & 48.6 & 21.7 & 126 \\
1948 & 51.0 & 15.5 & 105 \\
1949 & 44.7 & 17.5 & 104 \\
1950 & 55.7 & 16.2 & 86 \\
1951 & 61.2 & 15.2 & 74 \\
1953 & 45.0 & 15.6 & 104 \\
1954 & 44.8 & 13.2 & 82 \\
1955 & 47.6 & 12.5 & 81 \\
1957 & 49.1 & 14.2 & 80 \\
1958 & 50.4 & 12.7 & 80 \\
1959 & 55.8 & 13.6 & 77 \\
1960 & & & 62.9 \\
\hline
\end{tabular}

Table 5a: Major causes of morbidity from notifiable diseases in Nigeria 19841986 (Top twenty)

1986 Cases

1985 Cases

1984 Cases

Notifiable Diseases

\begin{tabular}{lllllll} 
& No & 100,000 & No & 100,000 & No & 100,000 \\
\hline & $1,020,071$ & $1,028.9$ & $1,284,402$ & $1,329.0$ & $1,242,882$ & $1,319.3$ \\
Malaria & 185,904 & 187.5 & 259,052 & 268.0 & 222,879 & 236.6 \\
Dysentery (all types) & 115,743 & 116.7 & 161,768 & 167.4 & 182,591 & 193.8 \\
Measles & 82,312 & 83.0 & 120,285 & 124.5 & 101,455 & 107.7 \\
Pneumonia & 42,306 & 42.7 & 70,514 & 73.0 & 55,139 & 58.5 \\
Gonorrhea & 42,193 & 42.6 & 92,266 & 95.5 & 62,751 & 66.6 \\
Whooping Cough & 26,975 & 27.2 & 31,788 & 32.9 & 36,710 & 39.0 \\
Schistosomiasis (all & & & & & & \\
types) & 21,387 & 21.6 & 76,266 & 78.9 & 65,932 & 70.0 \\
Chicken Pox & 17,168 & 17.3 & 1,425 & 1.5 & 1,302 & 1.4 \\
Meningitis (both & & & & & & \\
types) & 14,659 & 14.8 & 8,293 & 8.6 & 8,800 & 9.3 \\
Leprosy & 14,071 & 14.2 & 14,934 & 15.5 & 10,677 & 11.3 \\
Turberculosis & 9,991 & 10.1 & 18,156 & 18.8 & 5,941 & 6.3 \\
Viral Influenza & 9,247 & 9.3 & 16,586 & 17.2 & 12,756 & 13.5 \\
Filariasis & 8,234 & 8.3 & 7,518 & 7.8 & 3,610 & 3.8 \\
Ophthalmia & & & & & & \\
Neonatorum & 6,285 & 6.3 & 5,287 & 5.5 & 2,827 & 3.0 \\
Food Poisoning & 3,766 & 3.8 & 7,647 & 7.9 & 5,316 & 5.6 \\
Infective Hepatitis & 3,616 & 3.6 & 1,514 & 1.6 & 1,778 & 1.9 \\
Relapsing Fever & 3,327 & 3.4 & 4,359 & 4.5 & 5,042 & 5.1 \\
$\quad$ Trachoma & & & & &
\end{tabular}


Table 5b: Major causes of morbidity from notifiable diseases in Nigeria 19841986 (Top twenty)

1986 Cases 1985 Cases 1984 Cases

Notifiable Diseases

\begin{tabular}{lllllll} 
& No & 100,000 & No & 100,000 & No & 100,000 \\
\hline Tetanus & 2,269 & 2.3 & 2,679 & 2.8 & 2,437 & 2.5 \\
Onchocerciasis & 1,944 & 2.0 & 7,317 & 7.6 & 5,046 & 5.4 \\
Diphtheria & 1,871 & 1.9 & 1,996 & 2.1 & 733 & 0.8 \\
Infectious Yaws & 1,687 & 1.7 & 1,154 & 1.2 & 75 & 0.1 \\
Typhoid \& & 1,362 & 1.4 & 673 & 0.7 & 1,219 & 1.3 \\
Paratyphoid & & & & & & \\
Yellow Fever & 1,102 & 1.1 & 6 & 0.07 & 898 & 1.0 \\
Syphills & 1,026 & 1.0 & 1,641 & 1.7 & 1,214 & 1.3 \\
Sleeping Sickness & 716 & 0.7 & 74 & 0.1 & 83 & 0.1 \\
\hline
\end{tabular}

Mid- Year Population used: 1984 - 94, 205, 800; 1985 - 96, 641, 500; 1986 - 99, 141, 300

(Source: National Population Bureau, Lagos Publication dated January, 1984.

Table 6a: Measles in Nigeria

\begin{tabular}{lllllll}
\hline State & 1985 & Measles Statistics & & 1986 & Measles Statistics & \\
& $\begin{array}{l}\text { Population } \\
\text { at risk }(5 \%)\end{array}$ & $\begin{array}{l}\text { Vaccination } \\
(\%) \text { at risk }\end{array}$ & $\begin{array}{l}\text { Deaths } \\
\text { Reported }\end{array}$ & $\begin{array}{l}\text { Population } \\
\text { at risk(5\%) }\end{array}$ & $\begin{array}{l}\text { Vaccination } \\
(\%) \text { at risk }\end{array}$ & $\begin{array}{l}\text { Deaths } \\
\text { Reported }\end{array}$ \\
\hline Anambra & 309,105 & $27,610(8.9)$ & $647(-)$ & 316,930 & $71,718(22.6)$ & $514(-)$ \\
Bauchi & 208,500 & $35,737(17.1)$ & $19,714(78)$ & 214,240 & $96,029(44.8)$ & $122,196(40)$ \\
Bendel & 211,500 & $42,408(20.1)$ & $5,397(38)$ & 216,855 & $83,484(38.5)$ & $1,293(38)$ \\
Benue & 208,585 & $24,378(11.7)$ & $4,564(6)$ & 213,865 & $62,904(29.4)$ & $5,269(14)$ \\
Borno & 257,610 & $36,129(14.2)$ & $2,686(32)$ & 264,135 & $65,392(24.8)$ & $7,903(50)$ \\
Cross & 298,920 & $27,720(9.3)$ & $1,810(34)$ & 306,485 & $58,396(19)$. & $1,312(30)$ \\
River & & & & & & \\
Gongola & 223,905 & $36,129(16.1)$ & $29,460(240)$ & 229,570 & $70,844(30.9)$ & $30,070(345)$ \\
Imo & 315,640 & $28,818(9.1)$ & $2,066(1)$ & 323,630 & $67,203(20.8)$ & $2,234(88)$ \\
Kaduna & 352,220 & $54,318(15.4)$ & $14,473(242)$ & $361(135)$ & $92,313(25.6)$ & $15,402(485)$ \\
Kano & 496,305 & $64,080(12.5)$ & $17,275(411)$ & 508,870 & $47,129(9.3)$ & $14,893(434)$ \\
Kwara & 147,345 & $14,879(10.1)$ & $8,005(-)$ & 151,080 & $28,514(18.9)$ & $2,233(2)$ \\
Lagos & 171,710 & $70,248(40.9)$ & $15,672(269)$ & 178,715 & $175,286(98.1)$ & $7,895(118)$ \\
Niger & 102,660 & $25,755(25.1)$ & $2,672(115)$ & 105,260 & $76,107(72.3)$ & $1,378(22)$ \\
Ogun & 133,295 & $11,655(8.7)$ & $3,476(-)$ & 136,670 & $35,483(26.0)$ & $1,719(2)$ \\
Ondo & 234,595 & $44,676(19.0)$ & $2,124(-)$ & 240,535 & $51,341(21.3)$ & $1,688(3)$ \\
Oyo & 447,665 & $33,849(7.6)$ & $2,537(-)$ & 459,000 & $78,838(17.1)$ & $1,143(-)$ \\
Plateau & 174,175 & $47,020(27.0)$ & $8,592(77)$ & 178,585 & $131,485(73.6)$ & $1,208(18)$ \\
Rivers & 147,815 & $15,758(10.7)$ & $1,473(12)$ & 151,555 & $41,460(27.4)$ & $526(-)$ \\
Sokoto & 390,075 & $20,875(5.4)$ & $9,125(165)$ & 399,950 & $65,127(16.3)$ & $6,867(302)$ \\
All & $4,832,075$ & $662,439(13.7)$ & 161,768 & $4,957,065$ & $1,399,053$ & 115,743 \\
States & & & $(1721)$ & & $(28.2)$ & $(1991)$ \\
FCT & & 4,751 & & & 3,744 & \\
Abuja & & & & & & \\
Total & $4,832,075$ & $667,190(13.8)$ & $161,768(172$ & $4,957,0651$ & $1,402,797(28.3$ & 115,743 \\
& & & $1)$ & & & $(1991)$ \\
\hline
\end{tabular}


Table 6b: Measles in Nigeria

\begin{tabular}{|c|c|c|c|c|c|}
\hline Parameter & 1982 & 1983 & 1984 & 1985 & 1986 \\
\hline Population at risk ( $5 \%$ total) & $4,475,930$ & $4,591,590$ & $4,710,290$ & $4,832,075$ & $4,957,065$ \\
\hline Measles vaccination reported & $1,851,453$ & 958,324 & 834,231 & 667,190 & $1,402,797$ \\
\hline$\%$ Population at risk vaccinated & 41.4 & 20.9 & 17.3 & 13.8 & 28.3 \\
\hline Midyear population estimate & $89,518,600$ & $91,831,800$ & $94,205,800$ & $96,641,500$ & $99,141,300$ \\
\hline Measles cases reported & 139,785 & 136,778 & 182,591 & 161,768 & 115,743 \\
\hline $\begin{array}{l}\text { Measles cases/100,000 } \\
\text { population }\end{array}$ & 156.2 & 148.6 & 193.8 & 167.4 & 116.7 \\
\hline Measles deaths reported & 985 & 983 & 1,431 & 1,721 & 1,991 \\
\hline Case fatality rate $(\%)$ & 0.70 & 0.72 & 0.78 & 1.06 & 1.72 \\
\hline
\end{tabular}

\section{Child survival in Nigeria}

Records show that more than one million African babies die in the first month of life. Nigeria has one of the highest under-five mortality rates in Africa with figures of 235 and 198 per 1000 live births in 1990 and 2003 respectively as well as a high neonatal mortality rate of 48 per 1000 live births. Low immunization coverage, malaria, diarrhea, acute respiratory infections (ARI) and vaccine preventable disease in concert with malnutrition still account for ninety percent of childhood death irrespective of government's effort to reduce under-five mortality rate compared with other development countries.

Factors that tend to overwhelm conscious government efforts include:

a. Lack of coordination of vertical and horizontal activities by government officials and donor agencies.

b. Poverty at household level.

c. Poor government funding.

d. Uncoordinated and haphazard vital registration.

Some children die of multiple causes since underlying malnutrition is present in half of the children who die from:
a. Malaria.
b. Acute Respiratory Infections (ARI)
c. Measles.
d. Diarrhea.
e. Tuberculosis.
f. HIV/AIDS

Other factors contributing to morbidity and death of these children include:
a. Poor immunization status.
b. Household poverty.
c. Maternal illiteracy.
d. Poor living conditions with consequent poor child care during illness.

In the early 1990 's Nigeria had routine immunization rates over $80 \%$ which gradually dropped to $25 \%$ and is now only picking up. The international body recommended a public expenditure per capita of thirty-four US Dollars for the purpose. In Nigeria, less than ten US Dollars per capita is made available.

Malaria assumes the pride of place as cause of morbidity and mortality in infants and young children. It causes up to two hundred thousand deaths among under-five annually. Specifically. Malaria affecting pregnant mothers causes intrauterine growth restriction and low birth weight, consequently lowering child survival. It can also cause preterm birth, prenatal and neonatal mortality as well as severe anaemia requiring blood transfusion.

The Roll Back Malaria Initiative was introduced and it promised access to effective anti-malaria drugs, prompt treatment and use of insecticide treated nets.

Diarrhea illnesses rank second as cause of infant death, obviously more in rural areas. Children in North East are five times more likely to have diarrhea than their South West counter parts.

Vaccine preventable diseases are third in the list of cause of mortality. Records show that diphtheria, tetanus, poliomyelitis, measles and tuberculosis cause two hundred thousand deaths annually among children. This scourge can be reduced by sustained routine immunization if supplemented with cerebrospinal meningitis vaccine and tetanus toxoid for pregnant woman. The greatest decline in routine immunization was $13 \%$ in 2003 which embarrassingly was the lowest vaccination rate amongst African countries. The publicity about wild polio virus in North West and North Central regions of Nigeria is fresh in our memory.

Neonatal tetanus was responsible for eleven percent of infant mortality in 1999 a poor reflection of antenatal care of pregnant women as two doses of 
tetanus toxoid immunization during antenatal period would protect for three years. If kept up, a woman requires total of five doses to acquire protection during child bearing years.

Malnutrition as mentioned earlier, malnutrition is the underlying factor in more than fifty percent of childhood mortalities. The range of disorders includes protein energy malnutrition (PEM) manifesting as weight deficits and stunting as well as deficiencies of micronutrients like vitamin A, iron, iodine and zinc. This could be evidence of food shortage or severe disease within a short time.

UNICFE and WHO recommend exclusive breast feeding for six months, introduction of semisolids and solid at six months while continuing with breast feeding for eighteen to twenty-four months of life. Unfortunately in Nigeria only seventeen percent of infants below six months are exclusively breast feed.

During my over fifty years of practice, both in the government teaching hospital and private sectors, I found that quite a lot of our female compatriots both illiterate and so called educated ones really did not have a full grasp of successful breast feeding practice. Some mothers give plain water to babies with attendant risk of diarrhea and infection. They knew no better. In addition to this, some introduce complementary feeds too early. Records show that thirty-six percent of babies at four to five months of life are not having adequate food for their age. This obviously leads to malnutrition, frequent illnesses and even death. Breast milk alone is estimated to be able to prevent thirteen percent of under-five death.

As stated earlier, micronutrient deficiencies also abound among Nigeria children. Vitamin A, for instance, is essential for proper development of the immune and visual systems of children. If deficient, there is reduced resistance to infections. Vitamin A dietary intake has been found to be inversely associated with risk of diarrhea. Deficiency of this vitamin is widely recognized as cause of night blindness and xerophthalmia. In Nigeria more than nine million children and six million mothers are vitamin A deficient. Effort has been made to give vitamin A supplements but studies show that in 2003 only thirty-four percent of children aged six months to fifty-nine months received vitamin A supplementation.

Other micronutrients of high importance are iodine and iron. Iodine deficiency not only leads to goiter, impairment of mental and physical development in children but also to increased rate of abortion, stillbirth, and congenital abnormalities of babies and cretinism in children if deficient in mothers. Iron deficiency in the mother can lead to maternal and perinatal mortality, premature delivery and low birth weight and increased susceptibility to infections. In Nigeria it is claimed that twenty-nine percent of children under-five years of age are anaemic.

HIV/AIDS: Mother to child transmission (MTCT) of HIV can occur during:

Pregnancy in $10 \%-30 \%$ of cases.

Delivery in $40 \%-60 \%$ of cases

Breast feeding in $15 \%-20 \%$

As expected, the scourge of HIV/AIDS truncated the modest gains of child survival strategies in terms of reducing infant and under five morbidity and mortality. By the end of the year 2000 an estimated 2000,000 children under five years had died from HIV/AIDS acquired through mother to child transmission and further projections forecast up to 700,000 deaths by 2010 .

Maternal Morbidity and Mortality: Child survival is closely bound to maternal health and mortality. We are all aware that children who lose their mothers are more likely to experience increased risk of death and other complications like malnutrition. A study showed that children, especially females, who lose their mothers at birth, are ten times more likely to die than those whose mothers survive. WHO reports state that annual maternal death in Nigeria is 55,000 per annum. Many other women end up with serious post natal complications further increasing the risk of children at risk of morbidity. Improvement in maternal care and comprehensive maternal care during pregnancy and labour would help strengthen child survival.

Health Services: As a nation, we adopted the National Health Policy in 1988 and this was revised in 1996. The main objective of the exercise has been to provide Primary Health Care (PHC) as well as secondary and tertiary health care by referral. Primary Health Care includes:

Health Education

Adequate Nutrition

Safe water

Sanitation

Reproductive Health including family planning

Immunization against five major infection diseases

Provision of essential drugs

Disease control

Unfortunately, the laudable objective of this policy has been shattered by poor and irregular funding. It is a well known fact that the Nigerian government allocates far less than the WHO recommendation of $15 \%$ of her annual budget to the health sector. 
The little amount allocated is often subject to official bureaucracy and delay leading to failure to maintain infrastructure. This, taken with poor staff attitude the Nigerian factor seriously affects efforts to provide optimum childhood immunization services aimed at promoting child survival.

\section{Vulnerability of children}

Maternal care in the early formative years of childhood is crucial to physical and mental development. Any form of deprivation at this tender age may affect quality of life in the future and in extreme cases, prevent realization of full potential.

This deprivation may be due to extreme poverty, poor governance, armed conflicts or HIV/AIDS. Such deprived children, and particular orphaned ones, are usually exposed to all kinds of exploitation. Without ratification of the Convention of the Rights of the Child and a solemn pledge to safeguard children from harm and abuse, exploitation and neglect, we must answer the question. Are we doing enough?

The way out of course, is to embark on a crusade of female education as it is known that poor educational level of females is related to higher infant and under5 morbidity. Poverty coincidentally, goes hand-inhand with poor female education.

Maybe a few more unsettling statistics will provide the right perspective:

In 1980 poverty level was $27 \%$ or 17.7 million out of 65 million people.

In 1996 the level doubled to $65.6 \%$ or 67.1

million

In 1998 the level was $70.2 \%$ or $71 \%$ of the estimated 105 million inhabitants

In 2003, Nigeria was classed as having the $3^{\text {rd }}$ largest population of the poor in the world. The poor are mostly in the rural areas and because they are unable to get health facilities at close quarters, they experience a lot of ill health and obviously default in immunization schedules of their children. The poor mother herself has little, if any, access to maternal care with avoidable maternal and fetal complications, while lack of adequate sanitation and safe water compound her problem. In 1999, only $54 \%$ of Nigeria population had access to safe drinking water while $53 \%$ lived in households with poor sanitary means of human waste disposal.

Other problems hindering child survival is the belief of some of our compatriots in spiritual and supernatural forces. This quite often causes delay in seeking medical help for children.

\section{Efforts at improving child survival in Nigeria}

Some effort has been made by government to reduce mortality from malaria, vaccine preventable diseases, diarrhea and acute respiration infections. There are also effort directed at ensuring food security at household level and reducing micronutrient deficiencies through fortification of food and supplementation these efforts are supported by many international donors and partners who donate funds and provide technical assistance. These international agencies include:

\section{WHO}

World Bank

African Development Bank

United States Agency for International Development through its implementation partners UNICEF

\section{Funds from these agencies support:}

Formulation of policies

Plans and guidelines

Advocacy

Dialogue

Health Sector Reports

Capacity Building

Child and maternal health

Service delivery including

Access to adequate immunization services

Vitamin A supplementation

And also NGO research about child survival

Malaria control: Nigeria adopted the Roll Back Malaria (RBM) initiative funded by WHO, UNICEF, World Bank and UNDP in 1998 with the goal of reduce malaria burden worldwide by 2010 . The Nigeria Government hosted the African summit on RBM initiatives in 2000 which led to the signing of the ABUJA DECLARATION by the Presidents and Head of States of African countries. Following the Abuja Declaration, the National Malaria Programme was declared at National and Local Government Area Levels.

\section{Vaccine Preventable Diseases and Immunization}

The Expanded Programme on Immunization (EPI) was initiated in 1979 by World Health Assembly (WHA) and was re-launched in 1984 due to poor coverage. EPI was changed to NPI (National Programme on Immunization) and the supervising agency became a parastatal by Decree 12 of 1997. The object was to effectively control vaccine preventable disease like TB, poliomyelitis, Diphtheria, whooping cough, tetanus and measles as well as diseases of women of child bearing age through immunization and provision of vaccine. The 
primary responsibility of NPI has been to support the States and local governments in their immunization programmes by supplying them with vaccines, needles and syringes and cold chain equipment as may be required.

In 2003, UNICEF took over the job of international procurement of vaccines because of chronic shortage in the country. In addition, the WHO helped NPI with surveillance and technical assistance while USAID helped with social mobilization at grass root level. Late or non release of funds for NPI however, led to poor success of immunization in 2004.

In 1995, Integrated management of childhood illnesses (IMCI), was initiated by WHO to provide quality health care for children. Prior to introduction of IMCI, emphasis had been on vertical programmes aimed at controlling rampant diseases like ARI, diarrhea. In 1997 with the backing of WHO and UNICEF the Nigerian government adopted the IMCI and this became the main host for child survival effort.

Food and Nutrition Policy was approved by Nigeria in 1998 and published in 2001. The factors identified as major causes of malnutrition in Nigeria were:

\section{Poverty \\ Inadequate investment in social sector \\ Inadequate Dietary Intake \\ Disease}

The aim of the policy was to reduce under nutrition in children, women and the aged. Of particular interest was a 30\% reduction of severe and moderate malnutrition in under 5 children and to remedy micro nutrient deficiencies by $50 \%$ of current level by 2010 .

Achievements made in children nutrition include formation of National Committee of Food and Nutrition (NCFN). The partners in this venture include NCFN, WHO, UNICEF, USAID and the International Institute of Tropical Agriculture (ITTA). Other achievements include launching of National Breast Feeding Policy and encouragement of exclusive breast feeding through the Baby Friendly Hospital Initiative (BFHI) which now stands as women and child friendly health services. This move undoubtedly broadened the awareness of exclusive breast feeding.

Other efforts include micro-nutrients, salt iodinazation, and vitamin supplement of staple food. The activities of NAFDAC promoted and encouraged the moves. In addition, school meals and school health service are being implemented in over twelve states including the Federal Capital Territory. In addition to all these, improve maternal care service, safe mother hood initiative and health education services were put in place.
Child rights act: The child rights act was enacted in 2003. The objective has been to put the best interest of the child paramount in all actions involving the child.

The salient points of the Act are as follows:

a. Every child has a right to survival and development

b. Every child is entitled to enjoy the best attainable state of physical, mental and spiritual development

c. Every government in Nigeria shall:

Endeavour to reduce infant and child mortality rate;

Ensure the provision of necessary medical assistance and health care services to all children with emphasis on development of primary health care;

Ensure the provision of adequate nutrition and safe drinking water;

Ensure the provision of good hygiene and environmental sanitation;

Combat disease and malnutrition within the framework of primary health care through the application of appropriate technology; Ensure appropriate health care for expecting and nursing mothers;

Support through technical and financial means the mobilization of national and local community resources in the development of primary care of children.

Every parent, guardian or person having the care and custody of a child under the age of two years shall ensure that the child is provided with full immunization.

Other components include:

The right of the child to free, compulsory and universal primary education to be provided by the government.

It prohibits child marriage and makes it a punishable offence to marry or give out in marriage any person below the age of eighteen years.

It also prohibits child labour and makes it a punishable offence.

Consequent upon the Act, some States in Northern Nigeria have abolished child marriage while some in the South have abolished female circumcision.

More States are passing the child rights bill into law. The implementation of the Act will strengthen child survival in Nigeria and facilitate the attainment of desirable health status of the Nigerian child as well as the MDGS. As a result of international concern for the implementation of the child rights Act, UNICEF 
Established child friendly rights based school initiative in some educationally disadvantaged areas of Northern Nigeria, while the Ford Foundation support enhanced female education. Orphans and vulnerable children are also helped by UNCEF, UNAIDS and Government Millennium Goal (MDG) agency.

As a signatory to the MDG declaration, Nigeria is obliged to reduce extreme poverty, hunger, child and maternal mortality, combat HIV/AIDS and other disease. She should also promote universal primary education, gender equality and ensure environmental sustainability amidst global partnership for development by 2015. Each of the MDGs is directly or indirectly linked to the wellbeing of the child. Some responses of the federal Government of Nigeria were to initiate poverty alleviation programmes, Universal Basic Education Scheme and the National Policy on Women.

Some other laudable concurrent programmes include:

Roll back malaria programme

National water supply

Free treatment of some diseases

Provision of safe drugs strengthened by the founding of NAFDAC to curb the menace of fake and substandard drugs.

The objectives of the MDGS as laudable as they are, are being frustrated by funding and equivocal political will. Recently again Nigeria ranked $13^{\text {th }}$ poorest country in the world as $66 \%$. Of the population live below poverty line

\section{Conclusion}

Despite the acclaimed enormous wealth of Nigeria, and in spite of successive several intervention programmes for child survival in Nigeria, no significant impact seems to have been made. Nigeria still has the worst childhood mortality record in Africa as indicated by the under five mortality, as testified by the Federal Ministry of health report for2004-2006.

We have achieved $10 \%$ reduction in under 5 motarlity the least in Africa, while the average improvement in sub-Saharan Africa was about 34\%. The reasons for this debacle have been repeatedly recounted in this presentation.

We rank as the $13^{\text {th }}$ poorest country in the world despite our wealth of human and material resources because:

The health budget is low

Less than half the population has access to safe water
Only about $41 \%$ have access to adequate sanitation

Overall adult literacy is about $56 \%$ in females and $47 \%$ in males

These adverse factors limit access to adequate nutrition, quality health care and other basic services with special reference to the vulnerable groups woman and children.

Ninety percent of childhood morbidity and mortality are preventable if we regularly deal with malaria, diarrhea diseases, acute respiratory infection and vaccine preventable diseases. Two thirds of childhood death could be prevented by effective preventive and therapeutic intervention which are packed and made available today as child survival strategies. At household level, there must be promotion of breast feeding, correct use of ORT, education on complementary feeding and use of insecticide treated nets. These strategies are tools for achieving the $4^{\text {th }}$ MDG of reduction of childhood mortality rate by two-thirds in 2015 .

HIV/AIDS without doubt helped in reversing health development gains especially in sub-Saharan Africa. Nigeria accounts for $10 \%$ of Aids burden in the world, 4 million individuals live with the infection and there is a possibility of upsurge if serious action is not taken. As of 2005, one million Nigeria children were already orphaned by the disease. With HIV/AIDS, the scourge of tuberculosis naturally increased.

\section{Statistics UNAIDS 2000}

3.3 TO 3.8 Million people are living with HIV/AIDS

An estimated 520,000people are in need of antiretroviral drugs

About 300,000 have died of aids

About 1.2millionhave been orphaned

\section{Access to health care services and health care infrastructure}

Unless the poor has insurance cover, they can have no access to health care when it is needed.

Not only cost but also distance and travel time militate against the poor receiving quality health care. In the light of this, the health sector reform programme was initiated in 2003 to improve access to quality health services. These include:

\author{
National Health Act Bill \\ Traditional Medicine bill \\ Policies on Health care finance \\ Human Resources Development \\ Health Promotion \\ Public Private Partnership in Health
}


National drug policy

National Food and Nutrition Policy

The Blood transfusion Services

The poor are at the losing end as they are exposed to health risks and have less resistance to disease. They have reduced access to preventive and curative intervention just as they are more undernourished surrounded by poor hygiene and sanitation.

The wide gap in mortality between the rich and the poor seems to be widening and this can only be bridged if sincere effort is made by the government and the governed to implement to the last letter the enumerated programmes. Overall, improving access to health services and infrastructure especially for the poor is feasible if the health reform programme is pursued vigorously with sincere commitment from the presidency and the policy implementers.

In 2004, the National Health Bill came into place with provision for the respective roles of each tier of government. Health system was decentralized under Federal structure. The federal level became responsible for overall policy as well as tertiary services while the state level is responsible for the primary services.

\begin{tabular}{|lcc|}
\hline Number of Health workers in Nigeria, 2003/2004 \\
\hline Staff type & No of Staff & $\begin{array}{c}\text { No of Staff per } \\
\text { 100,000population }\end{array}$ \\
\hline Doctors & 35,000 & 28 \\
Nurses & 210,000 & 170 \\
Dentists & 2,500 & 2 \\
Pharmacists & 6,350 & 5 \\
Laboratory & & 1 \\
technicians & 690 & 91 \\
Community health \\
Workers & 115,800 & \\
\hline \multicolumn{3}{l}{$\begin{array}{l}\text { Rounded figures } \\
\text { 2006 }\end{array}$} \\
\hline
\end{tabular}

The number of paediatricians in Nigeria is about 750 . Egypt and South Africa are the two countries surpassing Nigeria in stock of human resources for health in Africa.

\section{Brain drain}

A study showed that of 5,334 physicians from SubSaharan African practicing in USA, nearly $80 \%$ originate from three countries Nigeria, South Africa and Ghana. Apart from Great Britian, USA,Canada, Nigerian doctors are in Saudi Arabia,Quatar, South Africa, Namibia, Lesotho, Jamaica, Trinidad and Tobago. We are all conversant with the reasons for the migration:

\section{Low pay}

Poor career prospects

Lack of opportunity for professional advancement.

Adverse social and political condition.

\section{Education and Training}

Eighteen fully and five partially accredited medical schools in Nigeria provide:
2,000 Doctors
5,000 Nurses
800 pharmacists between 2002 and 2003.

Nigeria's medical workforce is bedeviled by lack of coordination, failure to develop teamwork and annoying professional rivalry sometimes between doctors and nurses and perpetually between pharmacists and doctors.

Our unfortunate colleagues in remote areas suffer from poor working condition, lack of basic equipment, late payment of salary if paid at all, lack of drugs, physical dilapidation of infrastructures, poor or nonexistent comfortable accommodation. Oftentimes, they are forgotten and promotion delayed.

\section{Present Health Situation in Nigeria}

In the context of this presentation, let us look at health not simply as absence of disease or illness but as encompassing the state of complete physical, mental and social well being of the individual, the family and the community.

Some reports of the health situation in Nigeria are as follows:

In $2,000 \mathrm{WHO}$ put Nigeria in the $187^{\text {th }}$ position out of 191 countries,

In 2005, UNDP Human Development reports ranked Nigeria 158 out of 177 countries in the world in terms of overall Human Development.

In contrast, Ghana is ranked $120^{\text {th }}$. It is also noted that infant mortality and maternal mortality rates are higher in Nigeria than in South Africa or Ghana .

Malaria and tuberculosis remain major causes of death especially among children under five years of age. In 1999, malaria accounted for $30 \%$ of all deaths among infants under one year old and $20 \%$ of all deaths among children under 5 years between 1960 and 1999.

To make matters worse, Nigeria ranks low among countries in efforts aimed at reducing death among children age 5 years due to malaria. The average percentage reduction for the least developed 
countries in the world is $42 \%$ while that for Saharan Africa is $34 \%$.

The figures for individual countries are:

$\begin{array}{ll}\text { Ghana } & 53 \% \\ \text { South Africa } & 47 \% \\ \text { Kenya } & 42 \% \\ \text { Cameroon } & 40 \% \\ \text { Sierra Leone } & 19 \% \\ \text { Liberia } & 18 \% \\ \text { Nigeria } & 10 \%\end{array}$

Without much argument we can conclude that the health situation in our beloved country is in a deplorable state, despite our vast human material and abundant natural resources.

I am sure that if some of us here today are given the necessary tools, incentive and encouragement and genuine cooperation of all stakeholders in the healing profession, we can reverse this worrisome trend.

Perhaps paramount in the way forward is improving the stewardship role of the government as honestly as possible. In addition, unless the Articles of the Health Reform Programmes and Research are honestly and religiously implemented to the letter, we would not make progress.

The human resources that abound in Nigeria need to be managed in a dedicated, sincere and a purposeful manner. We need to tackle brain drain by investing heavily in training of new manpower and retraining of existing ones. In this global village type world, we must strive to provide the necessary tools and equipment for the health workers in addition to ensuring that these quality staff are given abundant incentive to retain them.

The powers that be need to strengthen the Primary Health Initiatives. It is imperative that we as a body should join hand with other stakeholders in children's health to put pressures on the government to fund health in line with World Health Organization guidelines and recommendations.

More effort should be put into education of our teeming populace on Exclusive Breast Feeding.

Most of the agencies put in place to make life worth living for all of us must be coordinated effectively not only to promote food security, improve literacy and hygiene but to make potable water available to the populace at all levels. These include:
Ministry of Agriculture

Ministry of Education

Ministry of Sanitation

Ministry of Water resources.

Most importantly, if as it seems we cannot eradicate corruption, it must be minimized at all levels.

On our part as Paediatricians, events over the years have shown that we have been relevant in the long going struggle to child survival in the last four decades of our venture on the scene. We have helped in putting in place the concern of child health and life despite recurrent frustrations most of the way.

The Paediatric Association of Nigeria has over the years helped in establishing and promoting all the necessary institutions to promote the well being and care of the Nigerian child up to the establishment of the Faculty of Paediatrics of the Nigeria Medical College which we are celebrating today. Our founding fathers would no doubt rest happily with the knowledge that the acorn which they planted unwittingly is gradually becoming an oak tree.

Permit me to mention those colleagues who started the crusade:

1. Dr. Ishaya Audu (Professor of Paediatrics)

2. Dr. Olikoye Ransome Kuti (Professor of Paediatrics)

3. Dr. Asuquo Antia (Professor of Paediatrics

4. Dr. Ralph Hendrickse (Professor of Paediatrics)

5. Dr.Anjorin Animashaun

6. Dr. Aaron Ifekwunigwe (Professor of Paediatrics)

7. Dr. Winifred Kaine

8. Dr. Theodore Okeahialam (Professor of Paediatrics)

9. Dr. Mike Ogbeide (Professor of Paediatrics)

10. Dr. Calvin Sinnette

11. The author of this lecture

Thank you. 